\title{
The Effect of Principal's Leadership and Work Climate on Teachers Leadership with Work Motivation as Intervening Variable
}

\author{
Juliana \\ PSF- School Development Outreach Jakarta \\ msjuliana08@gmail.com
}

\author{
Niko Sudibjo \\ Department of Educational Technology, \\ Faculty of Education, \\ Universitas Pelita Harapan Jakarta \\ niko.sudibjo@uph.edu
}

\begin{abstract}
Integrated Islamic Primary School Al Islam is one of the favorite Islamic schools in Kudus with " $A$ " level accreditation for three respective years. However, pre-study analysis shows there is a gap between the teachers' expectations and the realities. The purpose of this study is to identify the impact of principal's leadership and work climate on teachers' leadership at Al Islam with work motivation as intervening variable. The research is a quantitative approach, implementing a path analysis method which involves 40 teachers as the total population of the school. The data is calculated with Smart Partial Least Square (PLS) Software. The result shows that principal's leadership, work climate, and work motivation have a positive impact on teachers' leadership.
\end{abstract}

Keywords - teachers' leadership, principal's leadership, work climate, work motivation

\section{INTRODUCTION}

Developing teachers' leadership is the biggest challenge for most school leaders, including the leader at $\mathrm{Al}$ Islam, one of Islamic schools in Kudus, East Java. Established in 1978, Al Islam has 40 full time teachers who teach 526 students in 14 classes from first up to sixth grade. Al Islam achieves $\mathrm{A}$ in school accreditation for three respective years, which eventually makes it one of the favorite primary schools in Kudus.

A pre-study was conducted to identify problems faced in teachers' leadership development. A set of questionnaires was distributed to 23 teachers as respondents. [1] The questionnaire includes seven dimensions- colleague acceptance, teachers' interest on task, teachers' freedom, participation in decision making, innovation, teaching media availability, and task distribution. The instrument consists of two forms: the Actual Form measuring the real psychosocial environment, and the Preferred Form identifying the expected psychosocial environment. The results were analyzed and compared to identify the gap.

Figure 1 describes the gap between teachers' expectation (A-blue line) and real situation based on teachers' perception (B- red line).

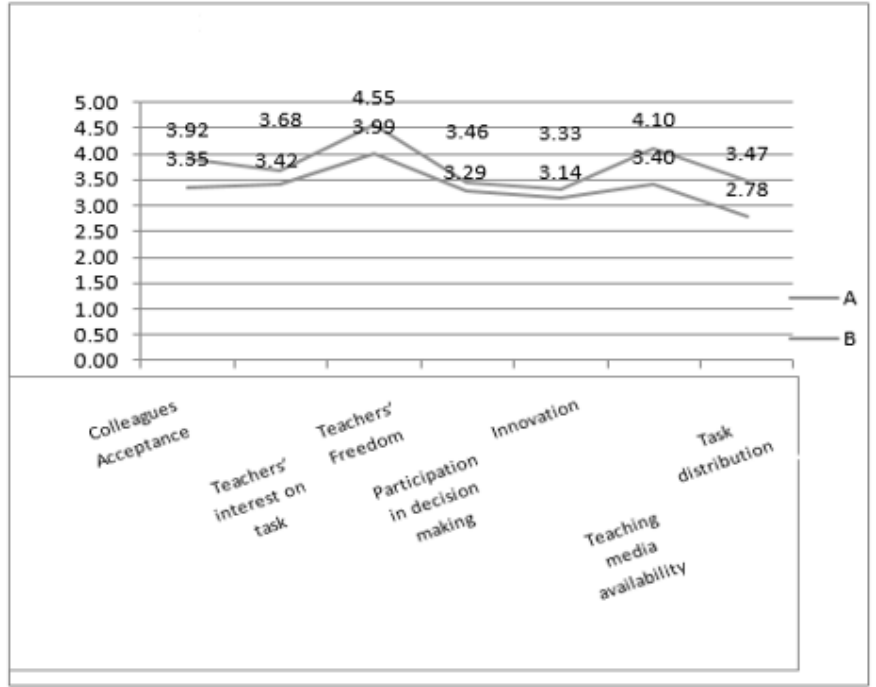

Fig. 1. Problems Identification at Al Islam

The graph above shows there is a gap between teacher's expectation and the real situation throughout the seven components. The biggest gap is in the teaching media availability with 0.70 points difference, suggesting that the school still lacks of teaching media resources. Task distribution is identified as the second biggest gap (0.69 points), showing that the principal does not distribute the tasks equally. The third biggest gap is colleagues' acceptance with 0.57 points difference. This might indicate that there are some teachers who do not get support from their peers.

The disparity in every single component above might hinder the whole development of teachers' leadership. Nevertheless, leadership in some of the teachers is observed in school routines. The success of some teachers in conducting school events or being subject coordinators is a proof that some teachers possess leadership skills. Being one of favorite Islamic schools in Kudus, Al Islam should develop teachers' leadership skills, which have not become parts of the school culture. Based on the background, the research will highlight the impact of principal's leadership and work climate on teachers' leadership with work motivation as intervening variable. 


\section{LITERATURE REVIEW}

\section{A. Teachers' Leadership}

[2] Teachers' leadership is a leadership practice in which teachers help, support, respect, and collaborate toward the expected goal. In this case, teachers' professional relationship plays a vital role in leadership development.

[3]Teachers' leadership also refers to a condition that enables the teachers to lead and collaborate with their colleagues as a form of reformation in education. To maximize development, school structure should provide some rooms for teachers to collaborate as well as to take part in the implementation of school action plan.

[4] Aside from that, teachers' leadership is considered as one of the leadership models in which each teacher is given an opportunity to develop his/her leadership skills both in and outside the class. The development of teachers' leadership involves empowering teachers in decision making, providing them with some alternatives on certain issues, and giving them more and higher responsibilities outside class. There are four dimensions in teachers' leadership: shared decision making, collaboration, active participation, and professional learning. These four dimensions are crucial in teachers' leadership development.

Based on the above elaborations, it can be synthesized that teachers' leadership is a process of empowering teachers in which the school provides some opportunities for teachers to lead and develop in a collaborative culture that supports each other for betterment.

\section{B. Principal's Leadership}

[6] Leadership is a skill possessed by a leader in influencing certain groups to achieve the intended objectives. [7] In accordance with that, leadership is also defined as a leader's ability in directing, coaching, mentoring, motivating, as well as inspiring his/her employees to attain the goal based on the organization's visions and missions.

[8] A study about principals' leadership in 2003 finds out that principal plays a significant role as a catalyst and motivator to empower teachers and staff in building their leadership capacity as well as to drive students for academic and non-academic achievements.

[9] In addition, a principal is required to possess three skills, which are technical skills including knowledge and skills in task organizations and problems solution; social skills relating to his/her ability in managing human resources effectively; and concept skills involving leaders in creating and translating ideas or concepts.

In conclusion, leadership is principal's capabilities in planning, making decisions, and interacting with teachers to achieve the desired organization's goals.

\section{Work climate}

[10] Work climate refers to a conducive working environment occurred as result of positive interactions among the school members. There are two types of work climate: open work climate as a result of respect, appreciation and cooperation among the school members; and close work climate referring to an unhealthy working competition, lack of collaboration, poor communication, and relatively low commitment of group members.

[11]Work climate is defined as a result of mutual interaction which is influenced by each member of the organization. Work climate affects the way employees work and think, which eventually would shape the school culture. [12] In addition to that, positive mutual interaction would lead to a conducive work climate resulting in a better working performance.

[13]Furthermore, work climate is a part of organization climate that is related to school's vision and missions, leadership, teachers' participation in decision making, as well as school's policies that mark the school's uniqueness.

[14] There are three dimension of work climate, which are relationship dimension, personal growth, and system dimension. Relationship dimension measures engagement of school members. Personal growth dimension evaluates teachers' ability in planning and doing the tasks efficiently, while system maintenance and system change dimension focuses on organization system including working pressure, control, innovation, policies, and physical environment.

From the above elaboration, it can be synthesized that work climate is a working environment or condition that is affected by the character, attitude, and behavior as well as interpersonal relationship of the school community in implementing schools' policies and procedures to achieve the intended goals.

\section{Work motivation}

[15] Work motivation refers to a person's desire that comes within him/herself to achieve the goal. Work motivation consists of three interrelated components: drive, direction, and persistence. Drive is an energy or motive that initiates a person's choice which directs his/her action. The success of one's action depends on his/her persistence to attain his/her goal.

[16] Furthermore, work motivation is defined as an internal or external drive that determines a person's action, effort, and attitude to obtain the desired outcome. ${ }^{[17]}$ In addition to that, Self-Determination Theory (SDT) highlights that work motivation is a drive that underlies one's action and behavior. SDT categorizes work motivation into three: a work motivation- a demotivating state of a person; internal work motivation- a strong drive that comes within oneself; and external work motivation- an instrumental motive in the form of appreciation, appraisal or others that would grow a person's interests.

[18] Moreover, work motivation is closely related to satisfier and dissatisfaction. Satisfier is associated with the work itself, achievement, recognition, and responsibility; while dissatisfaction correlates with the poor working environment, ineffective organization's policies, poor supervisory and delegating skills, as well as low recognition that lead to ineffectiveness and inefficiency.

From the above elaboration, it can be concluded that work motivation is an internal and external drive underlying a 
person's actions and/or behavior. A strong drive within teachers as school community members serves as a catalyst to attain the school goals. Owing to this fact, work motivation is considered the key factor in school development.

\section{E. Theoritical Framework and Analysis}

Figure 2 illustrates the impact of principal's leadership and work climate on work motivation as intervening variable towards teachers' leadership, as well as the impact of work motivation on teachers' leadership.

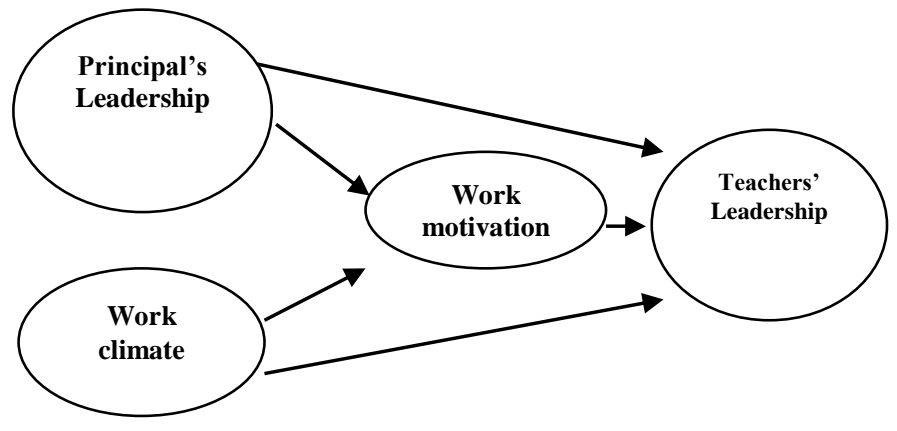

Fig. 2. Theoretical framework

Based on the framework, the hypotheses of this research are as follows:

H1 : There is an impact of principal's leadership on teachers' leadership at Al Islam

$\mathrm{H} 2$ : There is an impact of work climate on teachers' leadership at Al Islam

H3 : There is an impact of work motivation on teachers' leadership at Al Islam

H4 : There is an impact of principal's leadership on work motivation at Al Islam

H5 : There is an impact of work climate on work motivation at Al Islam

\section{RESEARCH METHOD}

The study is a quantitative research that evaluates principal's leadership and work climate as independent variables, work motivation as intervening variable, and teachers' leadership as dependent variable. Implementing a descriptive analysis, this research attempts to provide an objective description of teachers' leadership at Al Islam.

The research involves the total population (40 full time teachers) of Al Islam as respondents. The instrument used in the research is in the form of questionnaire applying Likert scale. [19] Likert scale measures respondents' behavior, opinions, and perceptions toward certain objects or phenomena. There are five options in the questionnaire, which are Strongly Agree, Agree, Neutral, Disagree, and Strongly Disagree.

Analysis of the data in this study implements two methods: descriptive statistics and hypothesis test. The data gathered was calculated using a Partial Least Square (PLS) method presented in the form of tables, diagrams, or graphs.

\section{A. Outer Model}

\section{RESULT AND DISCUSSION}

[20] Outer model evaluates the validity and reliability of the model by calculating convergent validity, composite reliability, and Average Variance Extracted (AVE) for each variable.

[21] The convergent validity measures the correlation between score of each item and score of each construct, in which the loading factor of $0.50-0.60$ is acceptable; while 0.70 is very reliable. ${ }^{[22]}$ In addition, the value of Average Variance Extracted (AVE) is considered valid if the score is equal to or above 0.50 ( $\geq 0.50$ ).

The loading factor of each item in the questionnaire ranges from 0.650 to 0.888 and the value of AVE of each variable is more than 0.50 . This suggests that the study has met the convergent validity requirement.

A data is considered valid if the value of the construct has met not only the convergent validity, but also discriminant validity. ${ }^{[23]}$ Discriminant validity describes the uniqueness and presents the phenomena of a construct. Discriminant validity test compares the value of AVE's square root for each variable with the correlation value of latent construct, in which the value of AVE's square root must be greater than the value of the latent construct.

The following table shows that the data has met the requirement of discriminant validity test. TABLE I. DISCRIMINANT VALIDITY TEST RESULT

$\begin{array}{cccc}\begin{array}{c}\text { Work } \\ \text { climate }\end{array} & \begin{array}{c}\text { Teachers' } \\ \text { Leadership }\end{array} & \begin{array}{c}\text { Principal's } \\ \text { Leadership }\end{array} & \begin{array}{c}\text { Work } \\ \text { motivation }\end{array} \\ \mathbf{0 . 7 1 3} & \mathbf{0 . 7 3 3} & & \\ 0.567 & 0.676 & \mathbf{0 . 7 5 8} & \\ 0.646 & 0.438 & 0.641 & \mathbf{0 . 7 4 0} \\ 0.441 & \text { a. Source: Data Analyzing Result using Smart PLS 3.0 (2015) }\end{array}$

Apart from the validity test, composite reliability test is also taken into account to justify the reliability of the data. [24] The value of composite reliability is around $0.60-0.70$. This study verifies that the composite reliability value of each variable is $0.804-0.902$, suggesting that each variable is reliable.

\section{B. Inner Model}

The R-Square test demonstrates the relationship and impact of independent variables on dependent and intervening variable. The result is presented as follows:

\begin{tabular}{|c|c|}
\hline TABLE II. & UARE TEST \\
\hline Variable & R-Square \\
\hline Principal's Leadership & 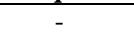 \\
\hline Work climate & - \\
\hline Work motivation & 0.247 \\
\hline Teachers' Leadership & 0.655 \\
\hline
\end{tabular}

The result suggests that $24.7 \%$ work motivation variable is explained by the principal's leadership and work climate, while the other $75.3 \%$ is explained by other variables. 
Meanwhile, $65.5 \%$ teachers' leadership variable is demonstrated by principal's leadership, work climate, and work motivation while the remaining $34.5 \%$ is expounded by other variables.

\section{Hypothesis Test}

Hypothesis test in this particular research refers to the path coefficient. If the path coefficient is equal to zero, hypothesis is unsupported. On the other hand, if the path coefficient is not equal to zero, hypothesis is supported. The following table highlights that each hypothesis is supported.

\begin{tabular}{|c|c|c|}
\hline \multirow{2}{*}{$\frac{\text { TABLE III. }}{\text { Hypothesis }}$} & OTHESIS TE & \\
\hline & $\begin{array}{c}\text { Path } \\
\text { Coefficient }\end{array}$ & Results \\
\hline $\begin{array}{c}\text { H1: There is an impact of principal's } \\
\text { leadership on teachers' leadership at Al Islam }\end{array}$ & 0.357 & Supported \\
\hline $\begin{array}{l}\mathrm{H} 2 \text { :There is an impact of work climate on } \\
\text { teachers' leadership at Al Islam }\end{array}$ & 0.285 & Supported \\
\hline $\begin{array}{l}\text { H3: There is an impact of work motivation on } \\
\text { teachers' leadership at Al Islam }\end{array}$ & 0.358 & Supported \\
\hline $\begin{array}{l}\text { H4: There is an impact of principal's } \\
\text { leadership on work motivation at Al Islam }\end{array}$ & 0.277 & Supported \\
\hline $\begin{array}{l}\text { H5: There is an impact of work climate on } \\
\text { work motivation at Al Islam }\end{array}$ & 0.284 & Supported \\
\hline
\end{tabular}

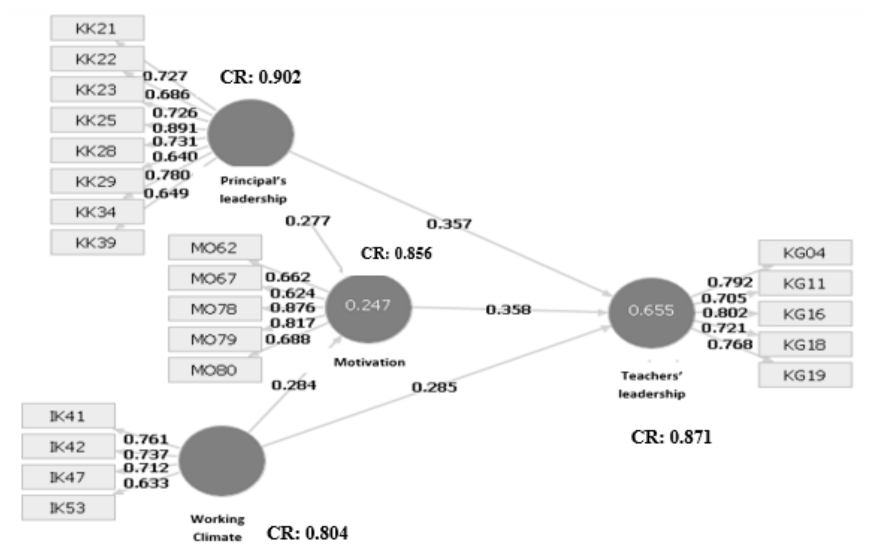

Fig. 3. The results of inner model, outer model and hypothesis test.

d. Source: Data Analysis Result using Smart PLS 3.0 (2015)

\section{DISCUSSION}

The study aims at analyzing the impact of principal's leadership and work climate on teachers' leadership with work motivation as intervening variable. The result of the hypothesis test verifies that all propositions are supported. The explanation of each hypothesis is as follow.

The first hypothesis, "There is an impact of principal's leadership on teachers' leadership at Al Islam", is supported. [25] The result shows that principal's leadership has a positive impact on teachers' leadership. This aligns with a study on teachers empowerment, pointing out that teachers' leadership will be fully developed under effective principal's leadership. The principal should allow each teacher to actively take part in problem solving and decision making.

The fact that teachers of Al Islam have been involved in curriculum and school action plan development suggests that the principal has given each teacher opportunities to actively participate in activities apart from teaching. Owing to the fact that principal is one of the key factors in teachers' leadership development, it is imperative to improve the effectiveness of principal's leadership.

To sum up, collaborative planning, teachers' professional development through dissemination, teachers' involvement in decision making and strategic plan, as well as teachers' active participation are some strategies of teachers' empowerment have been implemented at Al Islam. Unless the teachers are given some rooms to professionally develop, teachers' leadership will not be enhanced.

The test result of hypothesis 2, "There is an impact of work climate on teachers' leadership at Al Islam", proposes that work climate has a positive effect on teachers' leadership. [26] This is in line with the previous research on teachers' leadership, highlighting that one of the important pillars in teachers' leadership is feeling of trust in a positive work climate. If every member of an organization trusts each other, they will assist and support each other even though there is some argument from disagreement.

Research shows that informal support group among teachers, peer acceptance, respect, mutual understanding, professional sharing sessions, and collaborative working contribute to the work climate at Al Islam. The teachers concede that they have been working hand in hand toward the same goal. Reviewing the school policies and sharing teaching strategies as well as brainstorming with colleagues to find the right solutions have been parts of the school culture. Therefore, it can be concluded that positive work climate is indispensable to teachers' leadership. The better mutual understanding between teachers is, the better the teachers' leadership skills will be.

[27] The third hypothesis stating that "There is an impact of work motivation on teachers' leadership at Al Islam" aligns with a research which highlights that low work motivation is a result of low appreciation. Appreciation and reward have been the drives for teachers at Al Islam to put their best effort in doing their tasks.

[28] Furthermore, external work motivation such as appreciation and reward will eventually promote teachers' engagement. Teachers' leadership requires teachers' participation in and outside class, resulting in a higher working load. Benefits and compensation are kinds of reward that will increase teacher's engagement and commitment.

Regular teachers brainstorming sessions as a professional activity has been practiced in Al Islam. Discussions mostly cover teaching challenges, teaching learning approaches based on the current issues, as well as sharing any workshops topics to colleagues. Through empowerment, teachers' external work motivation will be developed and teachers' leadership will also be improved.

Another focus of the study is stated in the fourth hypothesis, "There is an impact of principal's leadership on work motivation at Al Islam". The study highlights that the teachers of Al Islam are motivated to accomplish their tasks well and that a good relationship occurs between teachers and 
the principal. Teachers' involvement in action plan and curriculum development as well as task delegation are some real actions that have been implemented to enhance the teachers' internal work motivation.

The result of the fourth hypothesis test suggests that there is a positive impact of principal's leadership on teachers' work motivation. The more effective the principal's leadership is, the higher the teachers' work motivation will be. As a result, the effectiveness of the principal in terms of planning, task organization, evaluation, as well as conflict management should be improved.

The fifth hypotheses stating "There is an impact of work climate on work motivation at Al Islam" highlights that peer acceptance, colleague and principal support, as well as professional relationship contribute to the work climate at $\mathrm{Al}$ Islam. These all elements increase teachers' working work motivation. Teachers of Al Islam concede that appreciation and support from their principal and colleagues will enhance their work motivation.

The hypothesis analysis expounds that positive work climate will increase teachers' working work motivation. Acceptance, support, and assistance are three other elements of positive work climate. [20] The conducive work climate will affect teachers' work motivation. This aligns with a research on work climate, emphasizing that teachers' empowerment and professional support would enhance teachers' work motivation. The study emphasizes that positive work climate should always be developed to enhance teachers' work motivation.

\section{CONCLUSION AND LIMITATION OF THE RESEARCH}

\section{A. Conclusion}

Based on the data analysis about the impact of principal's leadership and work climate on teachers' leadership with work motivation as intervening variable, it can be concluded as follows:

- There is a positive impact of principal's leadership on teachers' leadership at Al Islam.

- There is a positive impact of work climate on teachers' leadership at Al Islam.

- There is a positive impact of work motivation on teachers' leadership at Al Islam.

- There is a positive impact of principal's leadership on work motivation at Al Islam.

- There is a positive impact of work climate on work motivation at Al Islam.

\section{B. Limitations of The Research}

One of the limitations of the research is the number of variables being measured and analyzed. Focusing on only three variables- principal's leadership, work climate, and work motivation- the research aims at identifying the impact of those three variables on teachers' leadership. It is suggested to explore other dependent variables that are assumed to affect teachers' leadership, such as stress, teachers' commitment, and organization culture to obtain a comprehensive analysis.

Apart from the restricted number of the evaluated variables, another limitation is on the target school. The research was conducted in a private school at Kudus. To obtain a more comprehensive and representative data, the study should also be conducted in other schools, including public schools.

\section{AKNOWLEDGEMENT}

We thank Dr. Innocentius Bernarto (Universitas Pelita Harapan Jakarta) for assistance with statistical \& data analysis and his comments that greatly improved the manuscript.

\section{REFERENCES}

[1] Fisher, Darrell, and Barry Fraser. "School Climate: Assessing and Improving School Environments." Research Information for Teachers 2 (1990): 1-4.

[2] Lambert, L. Building Leadership Capacity in Schools . Alexandria: VA: Association for Supervision and Curriculum Development, 1998.

[3] Silva, D Y, R Gimbert, and J Nolan. "Sliding the doors: Locking and Unlocking Possibilities for Teacher Leadership." Teachers College Record 4 (2000): 779-780.

[4] Harris, Alma, and Daniel Muijs. Improving Schools through Teacher Leadership. London: McGraw Hill, 2005.

[5] Loc.cit

[6] Robbins, Stephen P, and Mary K Coulter. Management. Pearson, Prentice Hall, 2007.

[7] Pardey, David. Introducing Leadership. United Kingdom: Elsevier Ltd, 2007.

[8] Leithwood, Kenneth A, and Carolyn Riehl. What We Know about Successful School Leadership. Toronto: National College for School Leadership, 2005.

[9] Northouse, Peter G. Leadership : Theory and Practice. United States of America: SAGE , 2007.

[10] Miskel, Cecil G, and Wayne K Hoy. Educational Administration: Theory, Research and Practice. McGraw Hill, 2005.

[11] Keith, Davis; Newstorm, John W. Organizational Behavior. 7. Translated by Agus Dharma. Jakarta: Erlangga, 1985.

[12] Mullins, Laurie J. Management and Organizational Behavior. London: Prentice Hall, 2005.

[13] Adenike, Anthonia. "The Journal: Organizational Climate As A Predictor of Employee Job Satisfaction: Evidence from Covenant University." 4 (January 2011).

[14] Moos, Rudolf H, and Paul M Insel. Family, Work, and Group Environment Scales Manual. California: Consulting Psychologists Press, Inc, 1974.

[15] Greenberg, Jerald. Behavior in Organizations. England: Pearson, 2011.

[16] Colquitt, Jason A, Jeffrey A Lepine, and Michael J Wesson. Organizational Behavior: Improving Performance and Commitment in the Workplace. 4th. New York: McGram-Hill Education, 2015.

[17] Ryan, R M, and E L Deci. "Promoting Self-Determined School Engagement: Work motivation, Learning, and Well-Being." In Handbook on Work motivation at School, by Wentzel R K, \& A Wigfield. New York: Routledge, 2009.

[18] Factor, R. "The Relationship between Job Satisfaction and PerformanceEvaluation and Utility for Management." Human Resource Management. Australia, 1982.

[19] Nazir, Moh. Metode Penelitian. Bogor: Ghalia Indonesia, 2005.

[20] Ghozali, Imam, and Hengky Latan. Partial Least Squares: Konsep, Teknik dan Aplikasi Smart PLS 3.0. 2. Semarang: Universitas Diponegoro Semarang, 2015.

[21] Loc.cit

[22] Loc.cit

[23] Henseler, Jorg, Christian M Ringle, and Marko Sarstedt. "A New Criterion for Assessing Discriminant Validity in Variance-Based Structural Equation Modelling." Journal of the Academic Science (Springerlink), 2014: 115-135.

[24] Ghozali, Imam, and Hengky Latan, Op.cit., p. 75

[25] Harris, Alma, and Daniel Muijs, Op.cit., p. 100-120 
[26] Duignan, Patrick, and Michael Bezzina. "Teachers as Leaders of Educational Change." Educational Leadership Conference. Wollongong: University of Wollongong, 2006. 9.

[27] Loc.cit
[28] Harris, Alma, and Daniel Muijs. Teacher Leadership: Principles and Practice. Britain: National College for School Leadership, 2003.

[29] Ladyong, Brenda L. "Organizational Climate and Teachers' Work Work motivation: A Case Study of Selected Schools in Prachinburi, Thailand." Scholarly Journal of Education 3, no. 5 (August 2014): 52-57. 